\title{
Letter
}

\section{Co-assessment for fundamental change: a reply to Salomaa}

In our Oryx editorial (Sutherland et al., 2017) we argued that co-assessment of evidence with a range of stakeholders, including local communities, would typically represent the most cost-effective way of doing conservation science. Co-assessment involves considering what works, and what does not, based on a systematic collation of global and regional datasets alongside other forms of knowledge, such as the experience of local communities. Under circumstances in which there is good evidence of what is likely to work in a particular place, it does not seem efficient to coproduce new knowledge in the form of field-based scientific experiments involving local stakeholders. Where there is more limited evidence of conservation effectiveness, the issue is of sufficient societal importance, and the resources are available, then we stated it may make sense to co-produce new knowledge alongside local stakeholders.

We are glad that Salomaa (2018) agrees with us that it is irrational to ignore existing knowledge, which happens too often in conservation (Sutherland \& Wordley, 2017; Rose et al., 2018). We both agree that working with practitioner and stakeholder communities has benefits, including building trust (Lacey et al., 2018), helping to understand what people value (Rose, 2018), and adding important lay knowledge (Montana, 2017). There is evidence that such participatory conservation can lead to better informed and more acceptable conservation outcomes (e.g. Lazos-Chavero et al., 2016; Amit \& Jacobson, 2018). Other studies, however, find little evidence that participatory engagement actually improves conservation outcomes (e.g. Young et al., 2013).

Our key difference is whether co-production is the norm, carried out for each intervention with each community, or a rarer activity applied as resources allow. We welcome Salomaa's call for assessment of 'practical conservation improvement in long-term transdisciplinary studies that consider both the local and broader socio-ecological contexts'. In the context of co-production, this presumably means involving every community. An exceedingly rough back-of-the-envelope estimate of 10 years ('long term'), with three disciplines working with non-academic stakeholders ('transdisciplinary'), one researcher each at USD 50,000 annually for 10 interventions, across hundreds of thousands of global communities, illustrates the challenge, even if the estimate is orders of magnitude out. Hence, we consider the model of reviewing the evidence and applying it locally to be more realistic.

We have already collated many tests of conservation actions published in the main conservation journals, including social and natural science studies (Sutherland et al., 2018; Sutherland \& Wordley, 2018), and we are about to review studies containing elements of behavioural change research. There are many gaps that need filling, and this will involve the greater inclusion of social science into processes of evidence collation.

WJS acknowledges the support of Arcadia.

DAVID Christian Rose School of Environmental Sciences, University of East Anglia, Norwich, UK

E-maildavid.rose@uea.ac.uk

Gorm Shackelford and William J. Sutherland Department of Zoology, University of Cambridge, Cambridge, UK

\section{References}

Amit, R. \& Jacobson, S.K. (2018) Participatory development of incentives to coexist with jaguars and pumas. Conservation Biology, $32,938-948$.

Lacey, J., Howden, M., Cvitanovic, C. \& Colvin, R.M. (2018) Understanding and managing trust at the climate science-policy interface. Nature Climate Change, 8, 22-28.

Lazos-Chavero, E., Zinda, J., Bennett-Curry, A., Balvanera, P., Bloomfield, G., Lindell, C. \& Negra, C. (2016) Stakeholders and tropical reforestation: challenges, trade-offs, and strategies in dynamic environments. Biotropica, 48, 900-914.

Montana, J. (2017) Accommodating consensus and diversity in environmental knowledge production: achieving closure through typologies in IPBES. Environmental Science \& Policy, 68, 20-27.

Rose, D.C. (2018) Avoiding a post-truth world: embracing post-normal conservation science. Conservation and Society, https://doi.org/10. 4103/cs.cs_17_131.

Rose, D.C., Sutherland, W.J., Amano, T., González-Varo, J.P., Robertson, R.J., Simmons, B.I. et al. (2018) The major barriers to evidence-informed conservation policy and possible solutions. Conservation Letters, e12564.

SAlOMAA, A. (2018) Co-production for fundamental change: a response to Sutherland et al. Oryx, 52, 617.

Sutherland, W.J. \& Wordley, C.F.R. (2017) Evidence complacency hampers conservation. Nature Ecology \& Evolution, 1, 1215-1216.

Sutherland, W.J. \& Wordley, C.F.R. (2018) A fresh approach to evidence synthesis. Nature, 558, 364-366.

Sutherland, W.J., Shackelford, G. \& Rose, D.C. (2017) Collaborating with communities: co-production or co-assessment? Oryx, 51, 569-570.

Sutherland, W.J., Dicks, L.V., Ockendon, N., Petrovan, S. \& Smith, R.K. (2018) What Works in Conservation 2018. Open Book Publishers, Cambridge, UK.

Young, J.C., Jordan, A., Searle, K.R., Butler, A., Chapman, D.S., Simmons, P. \& WATt, A.D. (2013) Does stakeholder involvement really benefit biodiversity conservation? Biological Conservation, $158,359-370$. 